\title{
Coulisses
}

Revue de théâtre

25 | Hiver 2002

Varia

\section{R.A.S. et Kantor ?}

\section{Danielle Vingler}

\section{OpenEdition}

Journals

Édition électronique

URL : http://journals.openedition.org/coulisses/6115

DOI : 10.4000/coulisses. 6115

ISSN : 2546-9460

\section{Éditeur}

Presses universitaires de Franche-Comté

\section{Édition imprimée}

Date de publication : 1 janvier 2002

Pagination : 123

ISBN : 2-84627-052-X

ISSN : $1150-594 X$

\section{Référence électronique}

Danielle Vingler, «R.A.S. et Kantor? », Coulisses [En ligne], 25 | Hiver 2002, mis en ligne le 24 octobre 2019, consulté le 15 novembre 2019. URL : http://journals.openedition.org/coulisses/6115; DOI : $10.4000 /$ coulisses. 6115

Ce document a été généré automatiquement le 15 novembre 2019.

Coulisses 


\section{R.A.S. et Kantor ?}

\section{Danielle Vingler}

1 Une fois encore le plaisir partagé des spectateurs et des comédiens du TUFC, dont l'engagement « humour grinçant » rend, malgré la noirceur du propos, l'espoir possible d'un meilleur troisième millénaire.

2 Ce spectacle est de mon point de vue la version colorée et optimiste de la noire et très belle Classe morte de Tadeusz Kantor où l'on assistait à la ronde de ceux qui se souviennent, vieux, ternes, désabusés, plongés dans un passé sans joie, marionnettes pitoyables d'une fin de vie sans espoir.

3 Ici, il y a ceux qui vivent, jeunes, lucides, témoins sans complaisance de leur présent. Marionnettes énergiques, bondissantes habitées malgré tout d'un désir de vie.

4 Si le Théâtre Cricot de Kantor était le théâtre de la Mort, le TUFC, animé par Joseph Melcore, est bien celui « de la vie ».

5 Donc, longue vie à ce très beau théâtre d'images fortes, ici et ailleurs. 